\title{
Perfectionism in obsessive-compulsive and eating disorders
}

\section{Perfeccionismo no transtorno obsessivo-compulsivo e nos transtornos alimentares}

\author{
Berta Rodrigues Maia, ${ }^{1}$ Maria João Soares, ${ }^{1}$ Ana Gomes, ${ }^{2}$ Mariana Marques, ${ }^{1}$ \\ Ana Telma Pereira , ${ }^{1}$ Ana Cabral, ${ }^{1}$ José Valente, ${ }^{1}$ Sandra Carvalho Bos, ${ }^{1}$ \\ Michele Pato, ${ }^{3}$ Fernando Pocinho, ${ }^{4}$ Maria Helena Azevedo, ${ }^{1}$ António Macedo ${ }^{1}$
}

\begin{abstract}
Objective: The main aims of this article are twofold. First, to assess perfectionism dimensions in obsessive-compulsive disorder and eating disorders in comparison with psychiatric control (depression/anxiety) and non-clinical control groups. Second, to examine if perfectionism is specifically related to these different clinical conditions. Method: Thirty-nine outpatients with obsessive-compulsive disorder, 24 outpatients with eating disorders, 65 outpatients with a diagnosis of depression and/or anxiety, and 70 non-clinical participants completed the Portuguese version of the Multidimensional Perfectionism Scale. Results: Compared to non-clinical subjects, individuals of all clinical samples had significantly higher scores on Multidimensional Perfectionism Scale total score, Self-Oriented and Socially-Prescribed Perfectionism. There were no significantly differences in Self-Oriented Perfectionism and Multidimensional Perfectionism Scale total score in all the three clinical samples. Subjects from the eating disorders sample had significantly higher scores of Socially-Prescribed Perfectionism in comparison to obsessive-compulsive disorder and psychiatric control samples. Conclusion: Perfectionism showed to be related with this broad range of psychopathologies. However, the differences between eating disorders versus obsessive-compulsive disorder and psychiatric control on Socially-Prescribed Perfectionism warrant further investigation in order to clarify the specificity of this perfectionism dimension in eating disorders.
\end{abstract}

Descriptors: Personality; Obsessive-compulsive disorder; Eating disorders; Depression; Anxiety

Resumo

Objetivo: Este estudo tem dois objetivos principais. Primeiro, avaliar as dimensões do perfeccionismo no transtorno obsessivo-compulsivo e nos transtornos alimentares em comparação com duas amostras controle: psiquiátrica (depressão/ansiedade) e não clínica. Segundo, avaliar se o perfeccionismo é um traço de personalidade especificamente relacionado com estas diferentes condições clínicas. Método: 39 pacientes com transtorno obsessivo-compulsivo, 24 com transtornos alimentares, 65 com um diagnóstico de depressão el ou ansiedade (todos estes pacientes encontravam-se em regime de ambulatório) e 70 controles não clínicos completaram a versão portuguesa da Multidimensional Perfectionism Scale. Resultados: Comparativamente à amostra não clínica, todas as amostras clínicas apresentaram níveis significativamente mais elevados na Multidimensional Perfectionism Scale total, no Perfeccionismo Auto-Orientado e no Perfeccionismo-Socialmente-Prescrito. Não houve diferenças estatisticamente significativas no Perfeccionismo-Auto-Orientado e na Multidimensional Perfectionism Scale total nas três amostras clínicas. No entanto, a amostra com transtornos alimentares apresentou níveis significativamente mais elevados de Perfeccionismo-Socialmente-Prescrito, comparativamente à transtornos alimentares e à amostra psiquiátrica (depressão/ansiedade). Conclusão: O perfeccionismo revelou estar associado a uma grande variedade de condições psicopatológicas. Contudo, as diferenças encontradas entre a amostra de transtornos alimentares, de transtorno obsessivo-compulsivo e a psiquiátrica no Perfeccionismo-Socialmente-Prescrito necessitam de investigação subsequente no sentido de clarificar a especificidade desta dimensão com os transtornos alimentares.

Descritores: Personalidade; Transtorno obsessivo-compulsivo; Transtornos alimentares; Depressão; Ansiedade

\footnotetext{
${ }^{1}$ Institute of Medical Psychology, School of Medicine, Universidade de Coimbra, Portugal

2 Department of Educational Sciences, Universidade de Aveiro, Portugal

${ }^{3}$ Departments of Psychiatry and Behavioural Sciences, University Southern California, Los Angeles, USA

${ }^{4}$ Psychiatric Clinic, Hospital Universidade de Coimbra, Portugal
}

The present work was designed and developed in the Institute of Medical Psychology, School of Medicine, Universidade de Coimbra. 


\section{Introduction}

For some decades the clinical characteristics of perfectionism have been well described by many authors, underlying the fact that it has some adaptive and maladaptive qualities. ${ }^{1}$ Adaptive perfectionism involves the setting of high goals retaining the ability to be satisfied with one's performance. In contrast, maladaptive perfectionism is characterized by the setting of unattainably high standards, the inability to take pleasure in one's performance and uncertainty about one's capabilities. More recently, this personality trait has received increased attention due to the fact that it has been linked with several psychopathological states. ${ }^{2}$

The concept of perfectionism has evolved from an early unidimensional view, to a more complex multidimensional construct with both intrapersonal and interpersonal dimensions. ${ }^{3}$ In this context, two groups of investigators, ${ }^{4,5}$ from different conceptual approaches, independently developed two scales to assess perfectionism (that share the same name Multidimensional Perfectionism Scale - MPS). Frost et al. MPS 4 has a strong intrapersonal focus, whereas the Hewitt \& Flett MPS ${ }^{5}$ have a stronger interpersonal emphasis.

The Hewitt \& Flett MPS distinguishes three dimensions of perfectionism: 1) Self-Oriented Perfectionism (SOP) - an intrapersonal component, which entails perfectionist behaviors deriving from and directed to the self; 2) Socially Prescribed Perfectionism (SPP) - an interpersonal dimension which involves the perception that significant others have excessively high standards and expectations of perfection for oneself; 3) Other Oriented Perfectionism (OOP) - another interpersonal component which involves perfectionist standards and demands deriving also from the self, but which are imposed on others.

Frost et al.'s MPS measures the extent to which the person is concerned over making mistakes, sets high personal standards, feels criticized by his/her parents, feels that his/her parents have high expectations for him/herself and doubts his/her ability to perform actions.

The scales do not overlap completely. ${ }^{4,5}$ Although a few subscale items correlations are large (e.g., Concern over Mistakes and SPP; Personal Standards and SOP), most relationships are moderate in size, suggesting that the underlying perfectionism dimensions and constructs are fairly distinct. ${ }^{6}$

In this study we used the Hewitt \& Flett MPS since it is the only perfectionism scale validated for Portuguese studies. ${ }^{7}$

\section{Obsessive-compulsive disorder (OCD)}

Perfectionism has been closely related to OCD since the beginning of the last century ${ }^{8}$ and has played a major role in psychoanalytic theories of OCD and in clinical descriptions of the disorder. ${ }^{9}$ Although this trait has played a prominent role in the theorizing about OCD, little attention has been paid to it in research literature.

More recently, it has been suggested that perfectionism is a "necessary but insufficient trait" for the development of OCD. ${ }^{9}$ Patients with OCD have been described as tormented by an inner drive for certainty and perfection. ${ }^{10}$

The different theories linking perfectionism to OCD share several common themes. ${ }^{10}$ The predominant one is that perfectionist thinking and behavior represent an attempt to avoid something unpleasant (i.e., criticism, disaster, uncertainty, or lack of control). Perfectionism develops in an attempt to avoid uncertainty or in an attempt to establish control over one's environment. In either case, the major feature is the avoidance of mistakes rather than the achievement of goals. ${ }^{9}$
The first systematic study that compares OCD patients with non-clinical subjects was accomplished by Frost \& Steketee. ${ }^{11}$ The authors found that MPS total perfectionism and Concern over Mistakes were significantly elevated among OCD patients compared to non-clinical controls. These findings were subsequently replicated. ${ }^{12}$ In non-clinical samples, sub-clinical OC symptoms have been correlated to overall level of perfectionism and some of the Frost et al. MPS dimensions: Concern over Mistakes and Doubts about Actions. ${ }^{4,11}$ Other studies reported similar results. ${ }^{10}$ Despite this, sub-clinical and non-compulsive subjects did not differ on subscales measuring more interpersonal components of perfectionism such as Parental Expectations and Parental Criticism. ${ }^{9}$ Hewitt \& Flett $^{5}$ found that patients with OCD have significantly higher scores on SPP than non-clinical controls do.

The findings in clinical samples are limited and more systematic studies are needed.

\section{Eating disorders (ED)}

Several studies have examined perfectionism and ED and have concluded that this personality trait plays an important role as a risk factor for both the development and the maintenance of ED. ${ }^{13,14}$ Some authors suggest that anorexia nervosa (AN) and bulimia nervosa (BN) do not simply co-occur with clinical perfectionism but are in many cases the expression of perfectionism in the domain of eating shape or weight and their control. ${ }^{15}$

In non-clinical samples, higher levels of perfectionism have been associated with disordered eating behaviors. Some authors ${ }^{15}$ found that eating disorder symptoms were associated with two dimensions of the Frost et al. MPS: Concern over Mistakes and Doubts about Actions. Studies using the H\&F MPS found that SOP and SPP were related to abnormal eating attitudes/behavior. ${ }^{16}$

In clinical samples, studies using different measures of perfectionism found higher scores of perfectionism in patients with ED compared to a control group. ${ }^{17}$ Other studies have found similar findings suggesting that trait facets of perfectionism are elevated among women with AN as well as other ED compared to normal controls. ${ }^{18}$

Significantly higher scores in the H\&F MPS dimensions of SOP and SPP have been found in patients with ED. ${ }^{19}$ They found that both SOP and SPP discriminated anorexic, psychiatric and normal samples, suggesting that those dimensions of perfectionism may be specifically related to ED. Several studies have also shown that recovered patients maintain higher levels of perfectionism score, both in $\mathrm{AN}^{19}$ and $\mathrm{BN} .{ }^{20}$

With regard to multidimensional perfectionism and $\mathrm{BN}$, in a recent study ${ }^{21}$ it was found that those with BN had higher scores for SOP, but not for SPP. Thus, there is some evidence in clinical samples for the association of both SOP and SPP dimensions of perfectionism with $\mathrm{AN}$, but the evidence regarding these dimensions and $\mathrm{BN}$ is mixed. ${ }^{22}$ The author verified that eating disorder not otherwise specified (EDNOS) patients experienced significantly lower eating concern than did BN patients. In addition, they reported significantly less dietary restraint, which is in line with other studies. ${ }^{23}$ As briefly reviewed, there is strong evidence for the relationship between perfectionism and various psychopathological conditions and it is of utmost importance to clarify the nature of this association. One of these overlaps is a marked preoccupation with bodily appearance/ sensations, with associated behaviors performed to decrease anxiety brought on by these preoccupations (e.g. AN and binge eating).

To our knowledge, there is only one recent study ${ }^{24}$ that compares perfectionism levels in different psychopathological conditions (ED, 
OCD and Major Depression), but using the Frost et al. MPS. The studies that compare perfectionism levels in OCD patients are limited. Therefore, the aim of the present research is to compare perfectionism levels in OCD and ED versus psychiatric (depression/anxiety) and non-clinical control groups, in order to verify whether this personality trait is specifically associated with certain psychiatric conditions or is a non-specific vulnerability factor related with a broad range of emotional disorders. ${ }^{25,26}$ As pointed out, the majority of the research on perfectionism and ED has been based on a unidimensional conceptualization, and few studies used a multidimensional measure of perfectionism. ${ }^{27}$ In that sense, we intend to fill these gaps in the literature of perfectionism and psychopathology.

\section{Method}

\section{Sample}

The total sample comprised 205 subjects (156 females and 48 males, 1 subject had missing gender information) distributed in 4 groups: 1) OCD: 39 outpatients with OCD from Universidade de Coimbra Hospital, mean age 25.63 years (S.D. = 8.821; Range = 15-60); 2) ED: 24 outpatients with ED from Universidade de Coimbra Hospital mean age 25.63 years (S.D. $=8.821$; Range $=$ 15-60); 3) Psychiatric controls (depression/anxiety): 65 outpatients from Universidade de Coimbra Hospital with clinical diagnoses of depression and/or anxiety (14 males and 50 females, mean age 33.86 years (S.D. $=9.952$; Range $=16-56$ ), and 4) Non-clinical controls: 70 university undergraduate students from Medicine, Dentistry and Humanities courses of the Universidade de Coimbra, recruited during their respective classes ( 17 males and 53 females, mean age 23.14 years (S.D. $=1.053$; Range $=22-25$ ).

The subjects from the ED sample who had comorbid diagnoses of OCD and ED ( $n=7)$ were excluded from the analysis due to the small sample size. The patients with AN $(n=9)$, BN $(n=4)$, and EDNOS ( $n=11$ ) were combined for analyses into a single group (ED sample). This procedure is in accordance with two recent studies showing that these conditions share distinctive psychopathology and there is an evident diagnostic flux with these patients moving between these diagnostic states over time. ${ }^{28}$

\section{Diagnoses}

The diagnoses of the patients with OCD and ED were based on the assessment with the Portuguese versions of the Diagnostic Interview for Genetic Studies (DIGS) 29,30 and the Anxiety Disorders Interview Schedule for DSM-IV: Lifetime Version (ADIS-IV-L). ${ }^{31}$

The diagnoses of the subjects in the psychiatric control group (depression/anxiety) were based only on the clinical assessment of their psychiatrist. The exclusion of other psychiatric disorders and of comorbidity with OCD and ED, for all the patients of this sample, was also based in this clinical assessment. All the psychiatrists involved were senior clinicians with several years of outpatient clinic experience.

Diagnoses were not made for the non-clinical control group.

\section{Instruments}

The MPS is a 45-item questionnaire with a 7-point scale ranging from strongly disagree (score 1 ) to strongly agree (score 7 ), that generates scores based on three subscales, each with 15 items: 1) Self-Oriented Perfectionism (SOP); 2) Socially Prescribed Perfectionism (SPP); 3) Other Oriented Perfectionism (OOP). The H\&F MPS was translated (French version) into Portuguese and then back-translated ${ }^{32}$ by a bilingual professor; no significant differences were found between them.
The Portuguese version of the Multidimensional Perfectionism Scale (MPS) ${ }^{7}$ was completed by all subjects. The MPS total score is derived from the sum of scores for the individual, and showed a high internal consistency (Cronbach's Alpha $=0.884$ ), being the test-retest reliability over four weeks $(n=293) 0.843$ (Pearson $r$, $p<0.001$ ). Theoretically the scores may range from 45 to 315 . A higher score is considered as an indicator of higher levels of perfectionism. The Internal Consistency (Cronbach's Alpha) for the subscales were: SOP $(18$ items $)=0.893$; SPP $(15$ items $)=$ 0.842 ; OOP $(8$ items) $=0.663$ (all values were those obtained for the female sample).

\section{Ethics}

The data for this report were drawn from an ongoing research on Perfectionism and Obsessive-Compulsive Spectrum Disorders (FCT-POCTI/37569/PSI/2001). The main goal of this study, which was approved by the Medical Ethics Review Committee of the Universidade de Coimbra Hospital, was the investigation of the dimension "perfectionism" and its relationship with eating behavior pathology and with obsessive-compulsive phenomena. ${ }^{6}$ Participants, from which consent was obtained, completed the Portuguese version of the MPS. ${ }^{7}$ Patients from the three clinical samples were recruited at Psychiatric Clinic of Universidade de Coimbra Hospital. The subjects of the non-clinical sample were all university students who were recruited with the collaboration of their Professors. The study participants received no compensation.

\section{Statistical analysis}

The Statistical Package used for statistical analysis was SPSS, version 15.0 for Windows. To compare perfectionism differences between samples the One-Way ANOVA Test, the Least Significant Different Test and the Kruskal-Wallis Test were applied as appropriate, after analyzing the assumptions of normality of the variables. To verify if there were differences between samples by age in the scores of MPS dimensions an ANCOVA test was used.

\section{Results}

The MPS mean scores and standard deviations for all samples are presented in Table 1.

One-Way ANOVA was used to compare the samples mean age (OCD, ED, Psychiatric and non-clinical) and significant differences were found $(F(3,193)=34.686, p<0.001)$. The multiple comparisons revealed differences between the non-clinical and the Psychiatric sample $(p<0.001)$ and between the Psychiatric and the OCD and ED samples ( $p<0.001$ ).

To compare the scores in MPS dimensions among these samples, partialling out or removing the effect of age, ANCOVA was performed in which age was included as covariate (to ensure that results were accounted for diagnostic groups, and not for age). The effect of age was not significant in all MPS dimensions and total score.

Significant differences were found between the non-clinical sample and OCD groups, ED and Psychiatric control group in MPS total score $(F:(3,156)=5.652 ; p<0.001)$, SOP $(F:(3,172)=$ 5.199; $p=0.002), \operatorname{SPP}(F:(3,174)=10.721 ; p<0.001)$; but not to $\operatorname{OOP}(F:(3,176)=2.471 p=0.064)$ (Table 1$)$.

In fact, the non-clinical sample presented significantly lower scores when compared to the other three samples. Although no significant differences were found between the three clinical samples in SOP and MPS total score, it is important to note a gradual trend increase in mean scores, from the Psychiatric to OCD and ED sample in the same variables, except in SOP mean scores where 
Table 1 - Differences between groups in the mean scores (standard deviations) of the MPS scale

\begin{tabular}{|c|c|c|c|c|c|c|}
\hline \multirow[t]{2}{*}{ MPS } & Non clinical control & $\begin{array}{l}\text { Psychiatric } \\
\text { control }\end{array}$ & OCD & ED & $p$ & $\begin{array}{c}\text { Group comparisons } \\
\text { post-hoc }\end{array}$ \\
\hline & 1 & 2 & 3 & 4 & & \\
\hline SOP & $79.78(15.99)$ & $89.62(16.89)$ & $88.15(19.07)$ & $95.00(18.46)$ & $<0.002^{* * *}$ & $1<2^{\star \star \star}, 3^{\star \star}, 4^{\star \star \star}$ \\
\hline SPP & $43.27(11.98)$ & $51.85(11.26)$ & $52.18(15.31)$ & $60.72(14.98)$ & $<0.001^{* \star *}$ & $1<2^{* \star *}, 3^{* \star *}, 4^{* \star *} ; 2<4^{* \star *} ; 3<4^{* \star}$ \\
\hline OOP & $44.06(6.84)$ & $41.38(8.28)$ & $42.20(8.65)$ & $39.39(7.57)$ & 0.064 & NS \\
\hline Total & $180.95(25.77)$ & $198.24(25.79)$ & $200.03(33.64)$ & $210.05(33.96)$ & $<0.001^{* \star *}$ & $1<2^{\star \star \star}, 3^{\star \star \star}, 4^{* \star *}$ \\
\hline
\end{tabular}

${ }^{*}$ According to Least Significant Differences; ${ }^{* *} p<0.05 ;{ }^{* * *} p<0.01$ (two-tailed).

MPS - Multidimensional Perfectionism Scale; SOP - Self-Oriented Perfectionism; SPP - Socially Prescribed Perfectionism; OOP - Other Oriented Perfectionism; $O C D$ - Obsessive- Compulsive Disorder; ED - Eating Disorders; NS - Non-significant

the mean scores in the Psychiatric control group were higher than in the OCD sample.

Considering the ED sample, it was observed the presence of significantly higher SPP scores than in the Psychiatric control and the OCD samples. Statistical analyses showed that the OCD sample did not differ significantly from the Psychiatric sample in any perfectionism dimensions (Table 1 ).

\section{Discussion and conclusion}

The results of the present study are in line with the findings of other authors ${ }^{3,14}$ showing significantly higher scores on SOP, SPP and MPS total scores in all the clinical samples when compared to non-clinical controls.

Hewitt et al. verified that eating disorder symptoms are driven by the motivation to meet unrealistic standards set by the self (i.e. SOP). ${ }^{33}$ According to the literature, SOP may be more specific to ED than SPP. 32 Unexpectedly, in our study SOP did not discriminate between OCD, ED and Psychiatric control samples (depression/ anxiety). In that sense the absence of significant differences could be due to the fact that the majority of our ED sample had an EDNOS diagnosis. As already known, the EDNOS category represents the most common diagnosis made in outpatient settings but is the one most ignored by researchers because of its status as a "residual diagnosis" in the DSM-IV, or a disorder of clinical severity where the diagnostic criteria of BN or AN are not met. ${ }^{23}$

The high perfectionism scores that ED patients revealed when compared to the other three groups in SPP could be related to the unrealistic standards for physical attractiveness and thinness that are associated with unrealistic standards for other personal characteristics, with self-imposed goals and critical self-scrutiny. According to the literature this perfectionism dimension is highly associated with AN, as well as with BN.

To our knowledge there is only one study ${ }^{18}$ that compares perfectionism levels in AN, BN and EDNOS using the H\&F MPS and no differences were found between groups on any perfectionism dimensions. However, it is possible that patients with EDNOS could have a more prominent SPP, compared to AN and BN patients. In that sense, it would be interesting to explore the perfectionism role in all ED subtypes using a large sample.

A relationship between perfectionism and sub-clinical obsessivecompulsive symptomatology has been repeatedly mentioned in the literature. However, there is relatively little empirical research comparing OCD patients to non-clinical control participants. ${ }^{10}$ The first author who made this comparison was Ferrari, ${ }^{34}$ using the Perfectionism Cognitions Inventory as a measure of perfectionism.
In our study we found that the OCD sample had higher SOP, SPP and MPS total scores than the non-clinical group and that the OCD sample did not differ from the Psychiatric control group in any perfectionism dimensions. Shafran \& Mansell ${ }^{2}$ in their review stated that there is no evidence to support that SPP is higher in patients with OCD as compared to psychiatric controls.

The present data extend our knowledge about the relationship between perfectionism and OCD and ED. In that sense, it would be necessary to complement the general treatment of OCD and ED patients with therapy that specifically addresses perfectionism. Further studies are also required to determine whether this kind of therapy would influence treatment outcome in this particular patients.

A limitation of this study was the fact that some patients selected for the ED and OCD sample were currently depressed and, in fact, a significant number of those patients have a lifetime history of depression. In theory, the issue of specificity of perfectionism would be more easily investigated in "a pure" sample (i.e. with no depression history). However, a "pure" sample is extremely difficult to obtain, since the comorbidity between depression and OCD or $\mathrm{ED}$ is the rule rather than the exception. This disorder commonly co-exists with depression; data from the Epidemiological Catchment Area program demonstrated that $67 \%$ of patients with OCD had at least one episode of Major Depression during their lifetime. ${ }^{35}$ Similarly, regarding the comorbidity of OCD/ED with anxiety symptoms/disorders, as we already have mentioned, subjects with both ED and OCD were excluded from the study. However, the presence of other subthreshold anxiety disorders, such as limited symptoms of generalized anxiety disorder or social phobia, was not considered as an exclusion criterion.

It can also be seen as a limitation that the presence of comorbidity (depression/anxiety or other psychiatric disorders) was not controlled in the non-clinical sample but, again, in the real world there is no such thing as a "pure" control sample. Therefore, we cannot rule out the possibility that some symptoms of the disorders under study were present in the control subjects. We know that the main reason for students' self-referral in the outpatient clinic for psychological treatment and counseling at Universidade de Coimbra is anxiety disorders and stress-related problems, namely social anxiety and psychological distress associated with evaluative concerns. ${ }^{36}$ However, we believe that looking at the rate of this type of symptoms in the community and at the initial sample size of controls (more than one thousand), from which this subsample has been withdrawn, the magnitude of the effect is probably diluted and not very important.

Another limitation is the fact that we did not control for the potential effect of gender and level of education in the scores of the 
MPS dimensions among the samples. The main reason for not doing so was the fact that in the ED sample, as expected, the number of male patients was too small to conduct separate analyses with them and because it was not possible to obtain the information concerning the schooling level from the OCD, ED, and Psychiatric control samples.

This study also presents a number of strengths. It is one of the few studies that compare perfectionism levels in different groups (clinical and non-clinical). We used a multidimensional perfectionism measure instead of a unidimensional, as the majority of the studies in ED literature have done. Finally, since there are few studies comparing perfectionism levels in OCD patients versus non-clinical participants, the present study contributes to clarify this issue.

\section{Acknowledgments}

Work supported by the grant POCTI/PSI/37569/2001 from the Fundação para a Ciência e Tecnologia. There were no potential conflicts of interest.

\section{Disclosures}

\begin{tabular}{|c|c|c|c|c|c|c|c|}
\hline $\begin{array}{l}\text { Writting group } \\
\text { member }\end{array}$ & Employment & $\begin{array}{l}\text { Research } \\
\text { grant }\end{array}$ & $\begin{array}{c}\text { Other research grant } \\
\text { or medical } \\
\text { continuous education }{ }^{2}\end{array}$ & $\begin{array}{l}\text { Speaker's } \\
\text { honoraria }\end{array}$ & $\begin{array}{l}\text { Ownership } \\
\text { interest }\end{array}$ & $\begin{array}{l}\text { Consultant/ } \\
\text { Advisory board }\end{array}$ & Other ${ }^{3}$ \\
\hline $\begin{array}{l}\text { Berta Rodrigues } \\
\text { Maia }\end{array}$ & $\begin{array}{l}\text { Universidade } \\
\text { de Coimbra }\end{array}$ & - & - & - & - & - & - \\
\hline Maria João Soares & $\begin{array}{l}\text { Universidade } \\
\text { de Coimbra }\end{array}$ & - & - & - & - & - & - \\
\hline Ana Gomes & $\begin{array}{c}\text { Universidade } \\
\text { de Aveiro }\end{array}$ & - & - & - & - & - & - \\
\hline Mariana Marques & $\begin{array}{c}\text { Universidade } \\
\text { de Coimbra }\end{array}$ & - & - & - & - & - & - \\
\hline Ana Telma Pereira & $\begin{array}{c}\text { Universidade } \\
\text { de Coimbra }\end{array}$ & - & - & - & - & - & - \\
\hline Ana Cabral & $\begin{array}{l}\text { Universidade } \\
\text { de Coimbra }\end{array}$ & - & - & - & - & - & - \\
\hline José Valente & $\begin{array}{c}\text { Universidade } \\
\text { de Coimbra }\end{array}$ & - & - & - & - & - & - \\
\hline $\begin{array}{l}\text { Sandra Carvalho } \\
\text { Bos }\end{array}$ & $\begin{array}{c}\text { Universidade } \\
\text { de Coimbra }\end{array}$ & - & - & - & - & - & - \\
\hline Michele Pato & $\begin{array}{l}\text { University } \\
\text { Southern } \\
\text { California }\end{array}$ & - & - & - & - & - & - \\
\hline Fernando Pocinho & $\begin{array}{l}\text { Hospitais da } \\
\text { Universidade } \\
\text { de Coimbra }\end{array}$ & - & - & - & - & - & - \\
\hline $\begin{array}{l}\text { Maria Helena } \\
\text { Azevedo }\end{array}$ & $\begin{array}{c}\text { Universidade } \\
\text { de Coimbra }\end{array}$ & - & - & - & - & - & - \\
\hline António Macedo & $\begin{array}{l}\text { Universidade } \\
\text { de Coimbra }\end{array}$ & - & - & - & - & - & - \\
\hline
\end{tabular}

\section{* Modest}

** Significant

*** Significant. Amounts given to the author's institution or to a colleague for research in which the author has participation, not directly to the author.

For more information, see Instructions for authors.

\section{References}

1. Hamachek DE. Psychodinamics of normal and neurotic perfectionism. Psychology. 1978;15:27-33.

2. Shafran R, Mansell W. Perfectionism and psychopathology: a review of research and treatment. Clin Psychol Rev. 2001;21(6):879-906.

3. Flett GL, Hewitt PL. Perfectionism: theory, research and treatment. Washington, DC: American Psychological Association; 2002.

4. Frost RO, Marten P, Lahart C, Rosenblate R. The dimensions of perfectionism. Cogn Ther Res. 1990;14(5):449-68.

5. Hewitt PL, Flett GL. Perfectionism in the self and social contexts: conceptualization, assessment and association with psychopathology. J Pers Soc Psychol. 1991;60(3):456-70.

6. Enns MW, Cox BJ. The nature and assessment of perfectionism: a critical analysis. In: Flett GL, Hewitt PL, editors. Perfectionism: theory, research and treatment. Washington, DC: American Psychological Association; 2002. p.255-84.

7. Soares M, Gomes A, Macedo A, Santos, V, Azevedo MH. Escala multidimensional do perfeccionismo: adaptação à população portuguesa. Rev Port Psicos. 2003;5(1):46-55.

8. Janet P. Les Obsessions et la psychasténie. Alcan, Paris; 1903.

9. Rhéaume J, Freeston MH, Dugas MJ, Letarte H, Ladoucer R. Perfectionism, responsibility and obsessive compulsive symptoms. Behav Res Ther. 1995;33(7):785-94.
10. Frost RO, Steketee G, Cohn L, Greiss K. Personality traits in subclinical and non-obsessive-compulsive volunteers and their parents. Behav Res Ther. 1994;32(1):47-56.

11. Frost RO, Steketee G. Perfectionism in obsessive-compulsive disorder patients. Behav Res Ther. 1997;35(4):291-6.

12. Antony MM, Purdon CL, Huta V, Swinson RP. Dimensions of perfectionism across the anxiety disorders. Behav Res Ther. 1998;36(12):1143-54.

13. Macedo A, Soares MJ, Azevedo MH, Gomes A, Pereira AT, Maia B, Pato M. Perfectionism and eating attitudes in a Portuguese sample of university students. Eur Eat Dis Rev. 2007;15(4):296-304.

14. Shafran R, Cooper Z, Fairburn CG. Clinical perfectionism: a cognitivebehavioural analysis. Behav Res Ther. 2002;40(7):773-91.

15. Minarik ML, Ahrens AH. Relations of eating and symptoms of depression and anxiety to the dimensions of perfectionism among undergraduate women. Cognit Ther Res. 1996;20(2):155-69.

16. Halmi KA, Sunday SR, Strober M, Kaplan A, Woodside DB, Fichter M, Treasure J, Berrettini WH, Kaye WH. Perfectionism in anorexia nervosa: variation by clinical subtype, obsessionality, and pathological eating behaviour. Am J Psychiatry. 2000;157(11):1799-805.

17. Pratt EM, Telch CF, Labouvie EW, Wilson GT, Agras WS Perfectionism in women with binge eating disorder. Int J Eat Disord. 2001;29(2):177-86. 
18. Cockell SJ, Hewitt PL, Seal B, Sherry S, Goldner EM, Flett GL, Remick RA. Trait and self presentational dimensions of perfectionism among women with anorexia nervosa. Cognit Ther Res. 2002;26(6):74558.

19. Bastiani AM, Rao R, Weltzin, TE, Kaye WH. Perfectionism in anorexia nervosa. Int J Eat Disord. 1995;17(2):147-52.

20. Stein D, Kaye W, Matsunaga H, Orbach I, Har-Even D, Frank G, McConaha CW, Rao R. Eating related concerns, mood, and personality traits in recovered bulimia nervosa subjects: a replication study. Int J Eat Disord. 2002;32(2):225-9.

21. Lilenfeld LR, Stein D, Bulik CM, Strober M, Plotinicov K, Pollice C, Rao R, Merikangas KR, Nagy L, Kaye WH. Personality traits among currently eating disordered, recovered and never ill first-degree female relatives of bulimic and control women. Psychol Med. 2000;30(6): 1399-410.

22. Wade TA. Retrospective comparison of purging type disorders: eating disorder not otherwise specified and bulimia nervosa. Int J Eat Disord. 2007;40(1):1-6.

23. Binford RB, le Grange D. Adolescents with bulimia nervosa and eating disorder not otherwise specified-purging only. Int J Eat Disord. 2005;38(2):157-61.

24. Sassaroli S, Lauro LJ, Ruggiero GM, Mauri MC, Vinai P, Frost R. Perfectionism in depression, obsessive-compulsive disorder and eating disorders. Beh Res Ther. 2008;46(6):757-65.

25. Fontenelle LF, Cordás TA, Sassi E. Eating disorders and the mood and obsessive-compulsive spectrum. Rev Bras Psiquiatr. 2002;24(Supl III):24-8.

26. Corregiari FM, Nunes PV, Neto FL, Bernik M. Obsessive compulsive disorder and food phobia: psychopathologic and therapeutic aspects. Rev Bras Psiquiatr. 2000;22(1):23-5.

27. Bardone-Cone AM, Wonderlich SA, Frost RO, Bulik, CM, Mitchell, JE, Uppala S, Simonich H. Perfectionism and eating disorders: current status and future directions. Clin Psychol Rev. 2007;27(3):384405.

28. Milos G, Spindler A, Schnyder U, Fairburn CG. Instability of eating disorder diagnoses: prospective study. $\mathrm{Br} J$ Psychiatry. 2005; 187:573-8.

29. Nurnberger JI Jr, Blehar MC, Kaufmann CA, York-Cooler C, Simpson SG, Harkavy-Friedman J, Severe JB, Malaspina D, Reich T. from the MIMH Genetics Initiative Diagnostic Interview for Genetic Studies. Rationale, Unique Features, and Training. Arch Gen Psychiatry. 1994;51(11):849-64.

30. Azevedo MH, Dourado A, Valente J, Macedo A, Coelho I, Pato M, Pato $C$. The Portuguese-language version of the diagnostic interview for genetic studies. Am J Med Genet. 1993;3(3):189.

31. DiNardo P, Brown T, Barlow D. Anxiety Disorders Interview Schedule for DSMIV: Lifetime version. Albany State University of New York; 1994.

32. Labrecque J, Stephenson R, Boivin L, Marchand A. Validation de L'échelle Multidimensionnelle du Perfectionnisme Auprès de la population Francophone du Québec. Rev Franc Cliniq Comport Cogn. 1999;III(4):1-11.

33. Hewitt PL, Flett GL, Ediger E. Perfectionism traits and perfectionistic self-presentation in eating disorder attitudes, characteristics and symptoms. Int J Eat Disord. 1995;18(4):317-26.

34. Ferrari JR. Perfectionism cognitions with nonclinical and clinical samples. J Soc Beh Pers. 1995;10:143-56.

35. Obsessive Compulsive Cognitions Working Group. Cognitive assessment of obsessive-compulsive disorder. Behav Res Ther. 1997;35(7):667-81.

36. Pereira AMS. Concepções e práticas metodológicas em diferentes paradigmas de investigação. In: Oliveira L, Pereira A, Santiago R, editors. Investigação em educação. Abordagens conceptuais e práticas. Porto Alegre: Porto Editora; 2004. p.47-58. 